\title{
GENERALIZED FRYZE CONTROL STRATEGY FOR SHUNT AND SERIES ACTIVE POWER FILTER
}

\author{
Hardik Jayeshkumar Padariya ${ }^{1}$, Ch.V.Siva Kumar ${ }^{2}$, Chandni Yogeshkumar Joshi ${ }^{3}$ \\ ${ }^{1}$ ME Electrical, Electrical Department, Parul Institute of Engg, \& Tech., Vadodara, Gujarat, India \\ ${ }^{2}$ Assistant Professor, Electrical Department, Parul Institute of Engg, \& Tech., Vadodara, Gujarat, India \\ ${ }^{3}$ ME Electrical, Electrical Department, Parul Institute of Technology, Vadodara, Gujarat, India
}

\begin{abstract}
The active power filter controller is based on the instantaneous power theory. And it can be classified in two groups. The first one is based on the transformation from abc phase to three-orthogonal axes, and other is based on directly from abc. In first method abc phases are converted into $\alpha \beta 0$ transformation and is called as $p-q$ theory. In second method it deals with directly abc phase, so it is called as abc theory. In second theory current minimization method is used to apply in real time application. The second method is proposed as control strategy in this paper because it has some advantages over p-q theory. The shunt active power filter is used for current compensation and series active power filter is used for voltage compensation. The matlab based simulation is done in this paper.
\end{abstract}

Key Words: Active filters, Instantaneous active and reactive power, Instantaneous power theory, generalized fryze theory.

\section{INTRODUCTION}

After many efforts, power quality conditioner was developed, which can solved the problem related to power quality. Nowadays more number of electronic devices is used by industries and residences in electrical system. For proper working of these devices, we have to provide high quality of power supply. But these devices inject harmonics in distribution system. This is one of the major problems in electrical system. The various power quality disturbances are transients, interruptions, voltage sag, voltage swell, voltage collapse, harmonics etc. It has been identified that power quality can be degraded both due to utility side abnormalities as well as the customer side abnormalities. The active filter which have ability to compensate nonlinear load current and unbalance supply voltage and they are used as shunt active filter and series active filter respectively [5].

The most popular control theory, the instantaneous power theories are used. These are mainly two types. One of them is instantaneous $p-q$ theory. And second is instantaneous abc theory. Almost all active filter developed are based on the instantaneous $\mathrm{p}-\mathrm{q}$ theory. It works effectively for controlling the active filter and robust control system. On other side the instantaneous abc theory is also very effective for developing active filter and is called as generalized fryze theory, which is used the current minimization technique to implement in real time application. It has some advantage over the $\mathrm{p}-\mathrm{q}$ theory. Because controller based on $p-q$ theory is used the Clark transformation to calculate real and imaginary power by the use of those power it can possible to generate compensating quantities [1].

In this paper instantaneous abc theory is proposed for shunt and series active filter. Its fundamental is based on the $p-q$ theory but not used Clark transformation. The minimization method based on Lagrange Multiplier method is used. And it is called as generalized fryze theory.

\section{SHUNT ACTIVE FILTER}

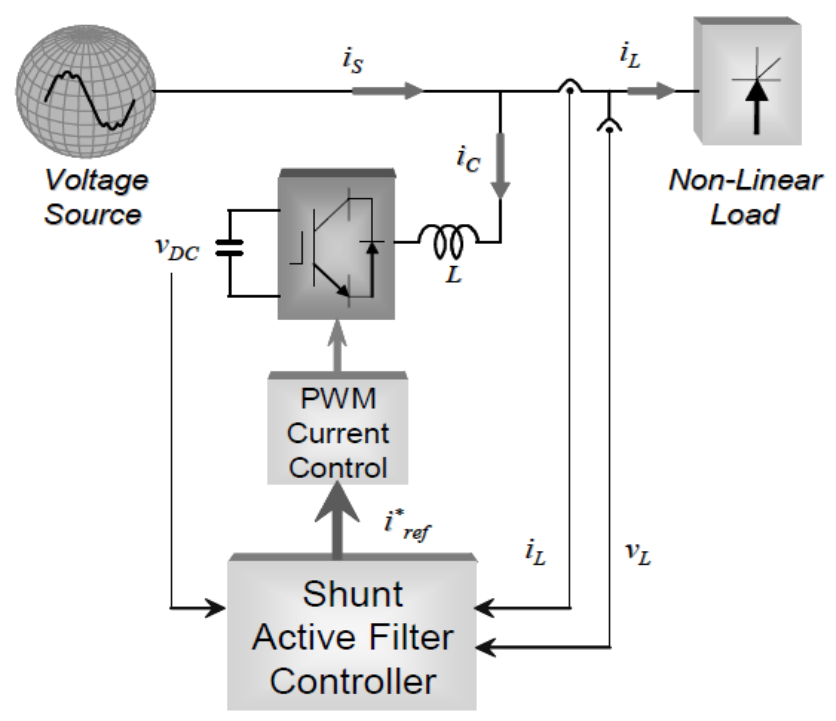

Fig -1: Shunt Active Filter 
Fig -1 shows the basic configuration of shunt active filter. The shunt active filter is used to generate reference current $i^{*}$ ref that will be generated by PWM converter. The compensating current $i_{C}$ compensates the load current $i_{L}$ to develop sinusoidal, balanced, and minimized compensated current is drawn from the network. The inputs of shunt active filter are load voltage and load current [2].

\subsection{Generalized Fryze Current Compensation}

Fig -2 shows the generalized fryze current control strategy for shunt active filter. This block diagram is used to calculate the compensating current. The first block is used to calculate the instantaneous fryze conductance by the use of load current and load voltage. This conductance is passed through the low pass filter and average value will be calculated, which is used to calculate the active current. In that calculation load voltage is also used. Now at last these active currents will be subtracted from the load current to calculate the compensating current [1].

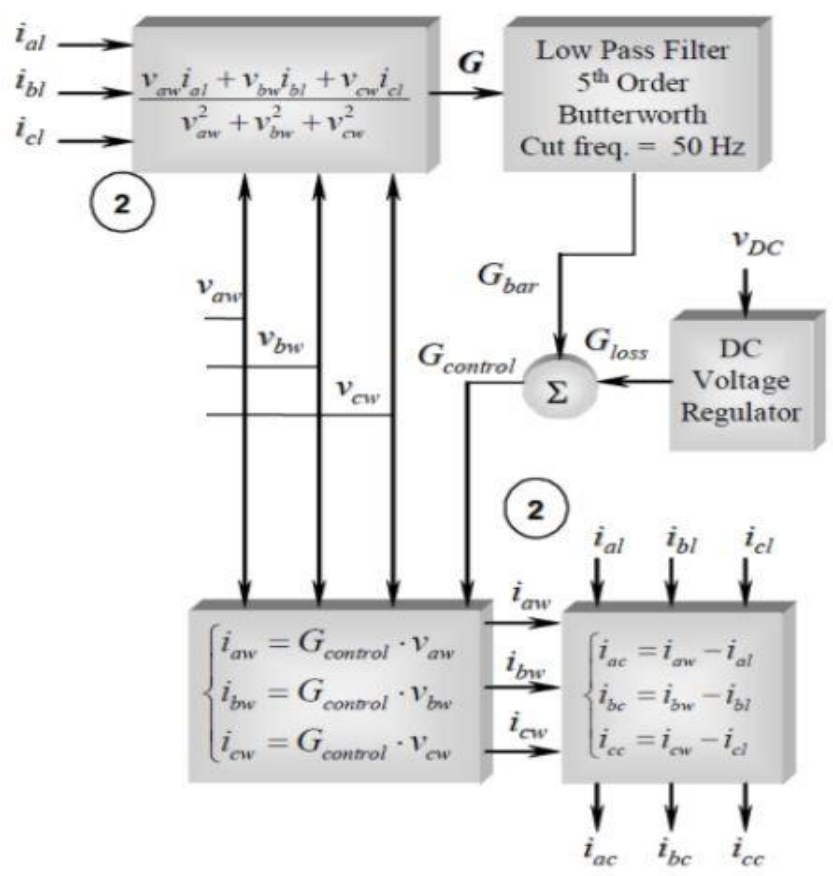

Fig -2: Generalized fryze current control strategy

\section{SERIES ACTIVE FILTER}

Fig -3 shows the basic configuration of series active filter. The series active filter is used to generate reference voltage $\mathrm{v}^{*}$ ref that will be generated by PWM converter. The compensating voltage vc compensates the load voltage $\mathrm{v}_{\mathrm{L}}$ to develop sinusoidal, balanced, and minimized compensated voltage $\mathrm{v}_{S}$ drawn from the network. The inputs of series active filter are load voltage and load current [3].

\subsection{Generalized Fryze Voltage Compensation}

Fig -4 shows the generalized fryze voltage control strategy for series active filter. This block diagram is used to calculate the compensating voltage. The first block is used to calculate the instantaneous fryze resistance by the use of load current and load voltage. This resistance is passed through the low pass filter and average value will be calculated, which is used to calculate the active voltage. In that calculation load current is also used. Now at last this active voltage will be subtracted from the load voltage to calculate the compensating voltage [1].

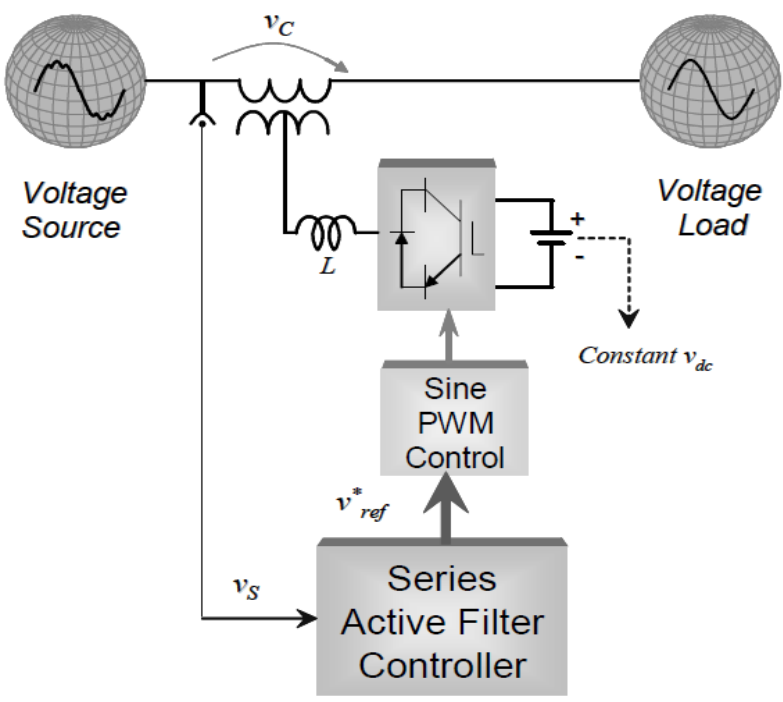

Fig -3: Series active filter

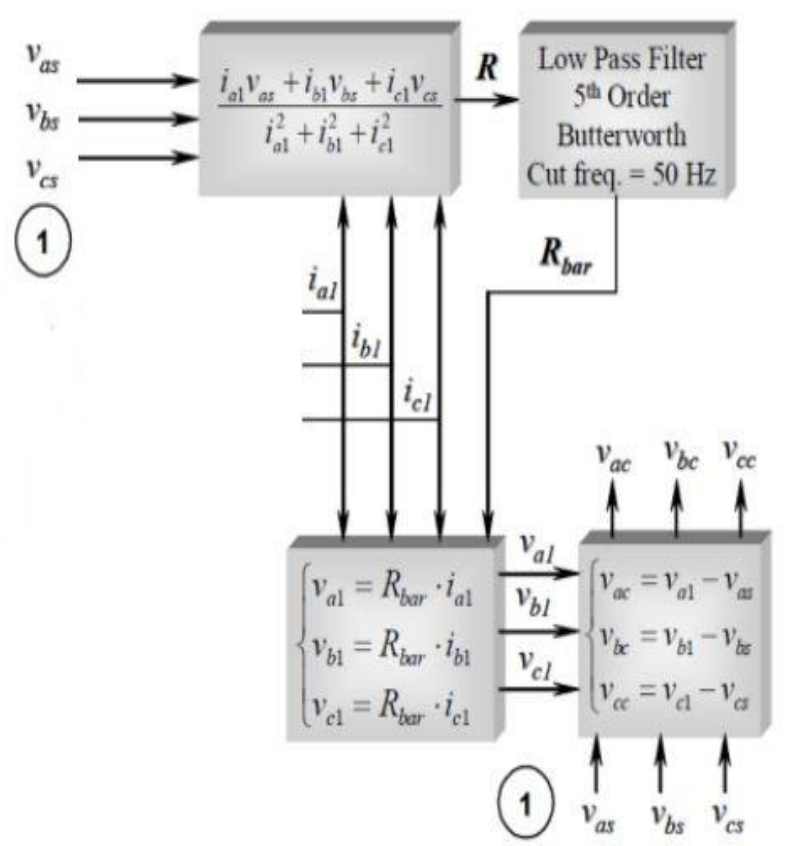

Fig -4: Generalized fryze voltage control strategy 


\section{SIMULATION RESULTS}

\subsection{Simulation Parameters of Shunt Active Filter}

Source (3-Phase)

-Voltage $=400 \mathrm{~V}(\mathrm{Ph}-\mathrm{Ph})$

-Frequency $=50 \mathrm{~Hz}$

Series Impedance

-Resistance $=0.001 \mathrm{ohm}$

-Inductance $=10-8 \mathrm{H}$

Load

Rectifier with $10 \mathrm{ohm}$ resistive load as non-linear load is taken from starting of simulation

Unbalanced load ( $\mathrm{Ra}=2 \mathrm{ohm}, \mathrm{Rb}=4 \mathrm{ohm}, \mathrm{Rc}=6 \mathrm{ohm})$ is taken in simulation at 0.03 second

Coupling Inductor $=1.2 \mathrm{mH}$

Shunt Active Power Filter Inject at 0.06 second

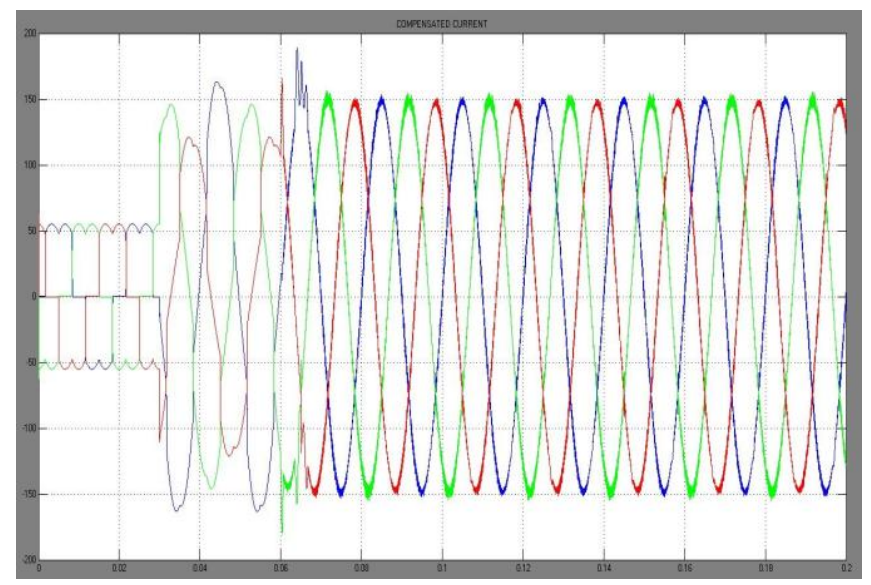

Fig -5: Compensated current

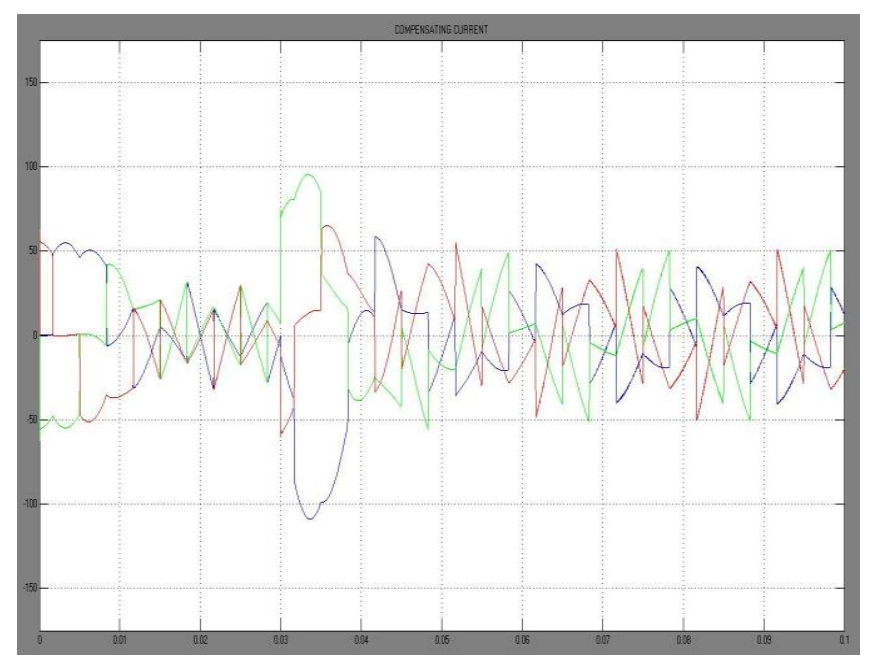

Fig -6: Compensating current

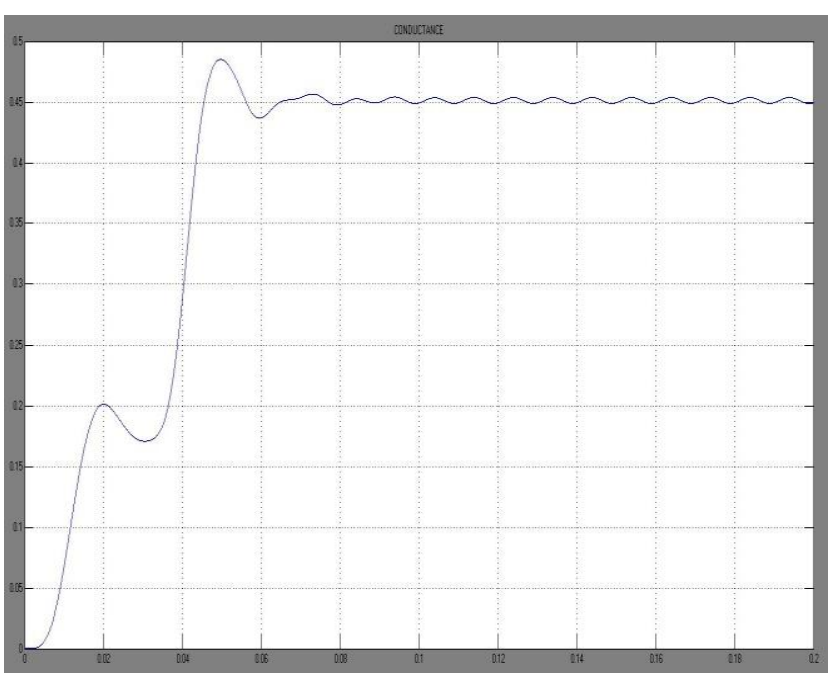

Fig -7: Active fryze conductance

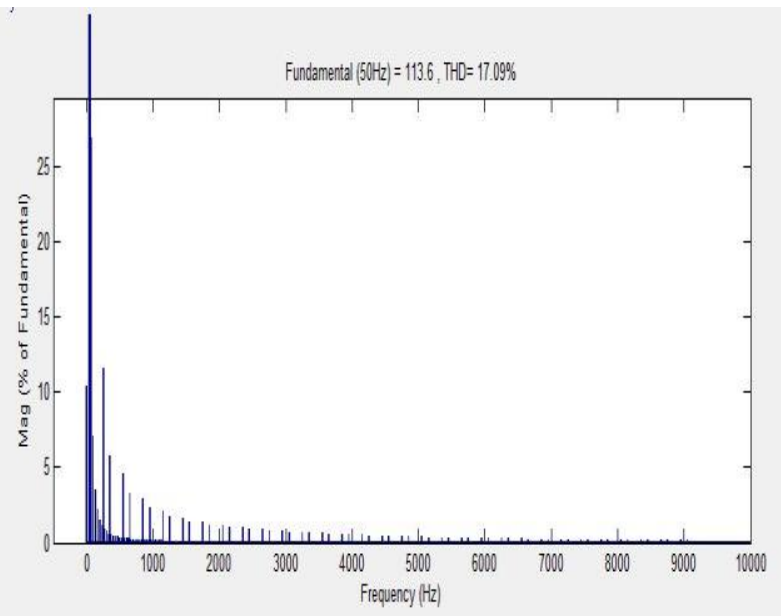

Fig -8: FFT analysis of load current without shunt APF

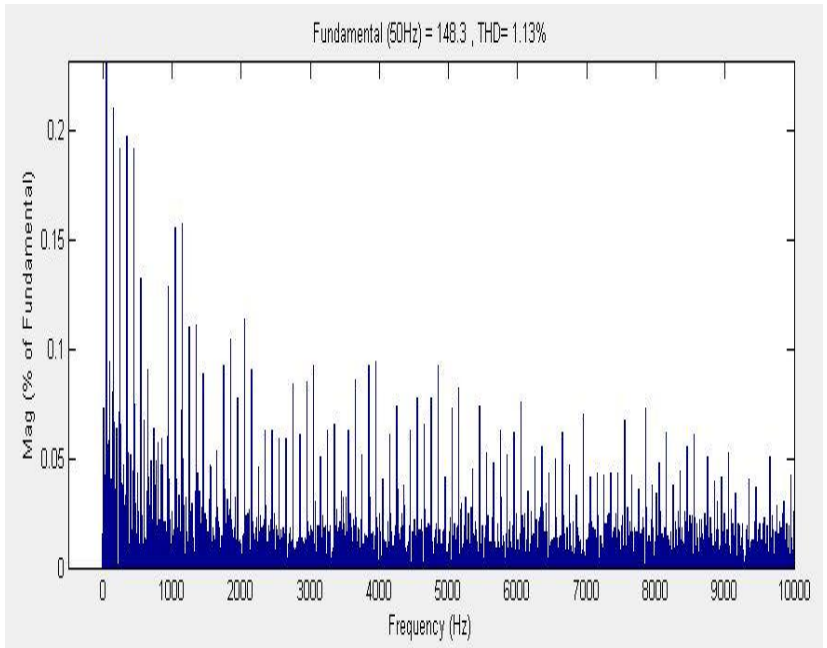

Fig -9: FFT analysis of load current with shunt APF 


\subsection{Simulation parameters of series active filter}

Source (3-Phase)

-Voltage $=400 \mathrm{~V}(\mathrm{Ph}-\mathrm{Ph})$

-Frequency $=50 \mathrm{~Hz}$

Series Impedance

-Resistance $=0.001 \mathrm{ohm}$

-Inductance $=10-8 \mathrm{H}$

Load

Rectifier with $1000 \mathrm{ohm}$ resistive load as non-linear load is taken from starting of simulation

Unbalanced load ( $\mathrm{Ra}=200 \mathrm{ohm}, \mathrm{Rb}=400 \mathrm{ohm}, \mathrm{Rc}=600 \mathrm{ohm})$ is taken in simulation at 0.03 second

Coupling Inductor $=1.2 \mathrm{mH}$

Shunt Active Power Filter Inject at 0.06 second

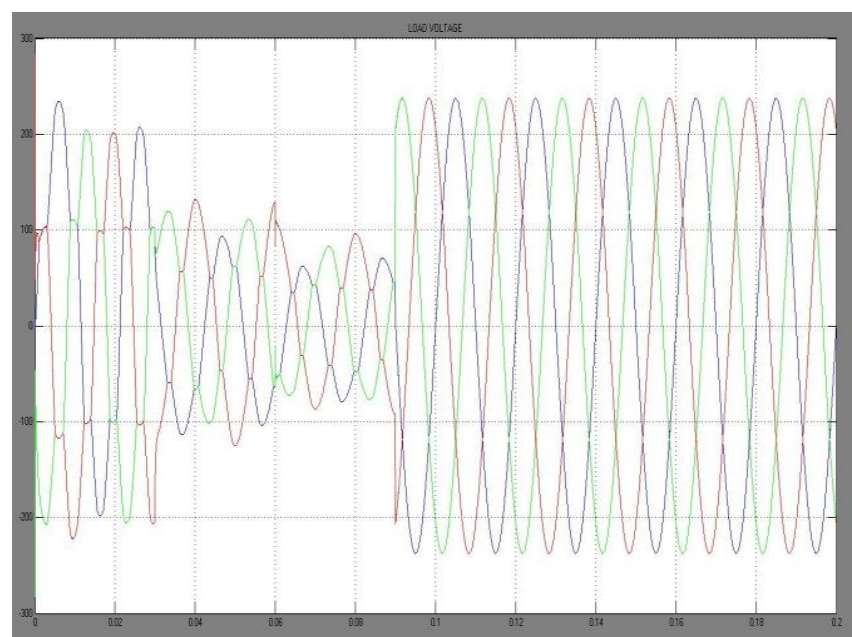

Fig -10: Compensated voltage

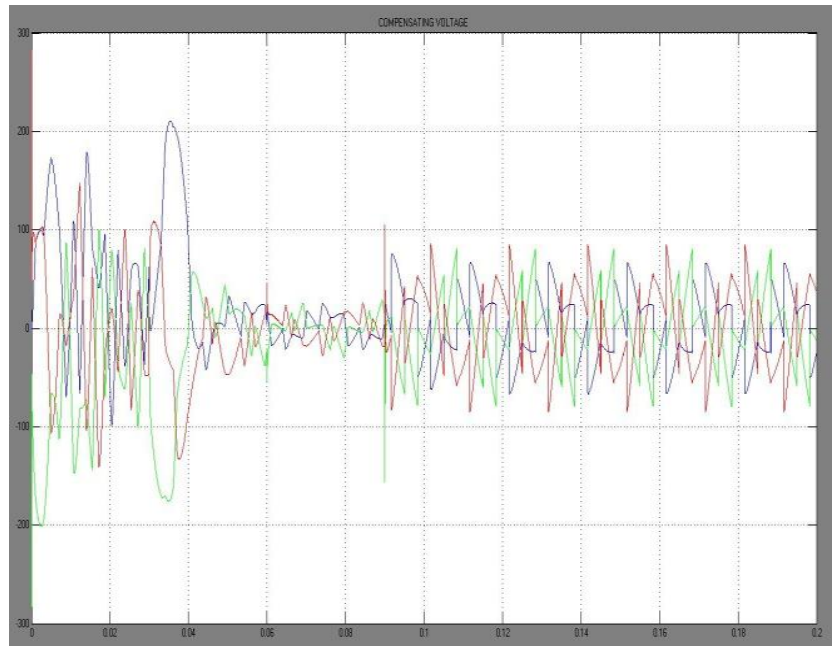

Fig -11: Compensating voltage

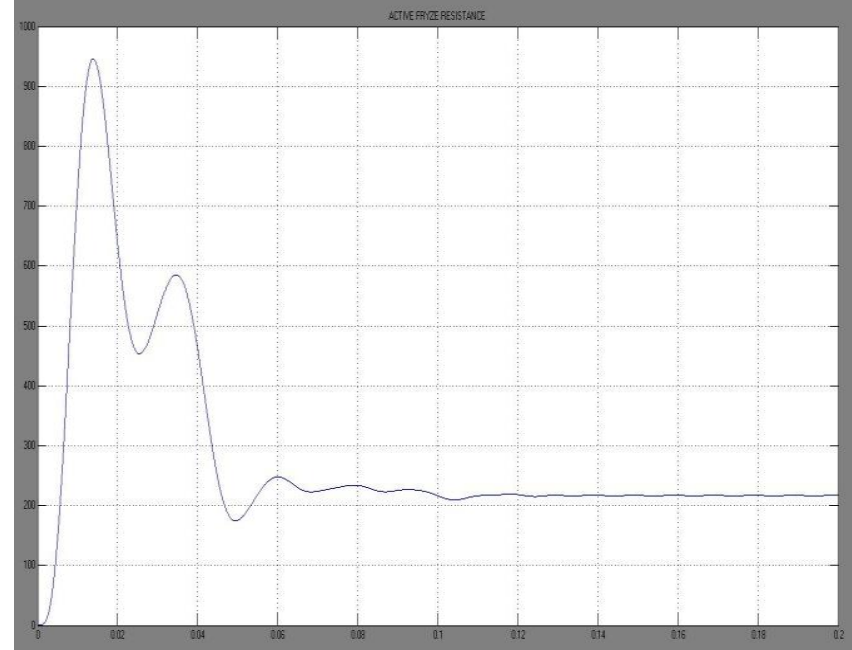

Fig -12: Active fryze resistance

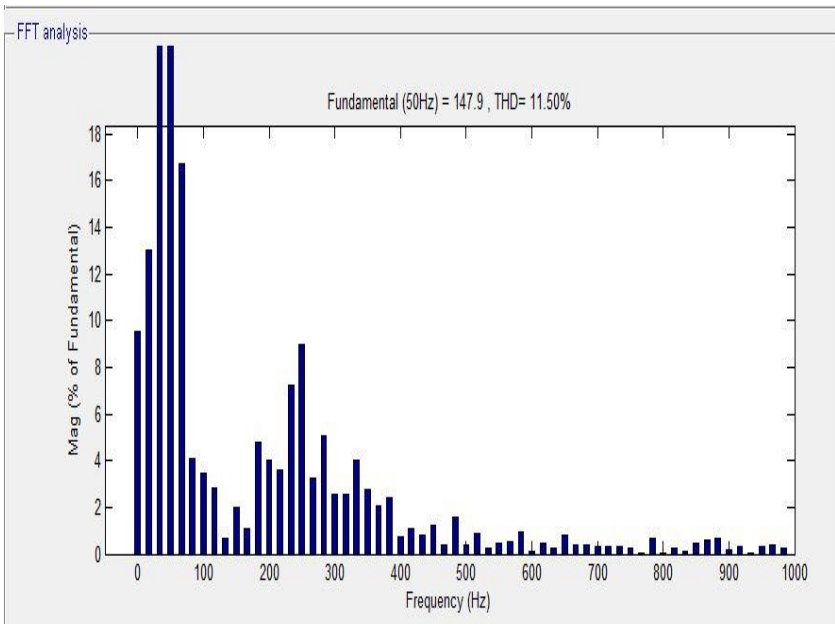

Fig -13: FFT analysis of load voltage without series APF

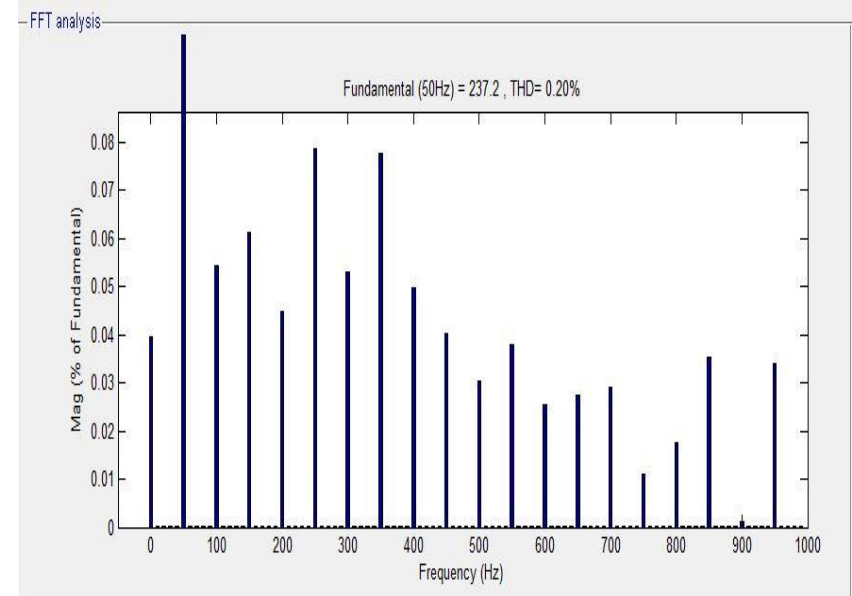

Fig -14: FFT analysis of load current with series APF 


\subsection{Simulation Result Table}

Table -1: Result Table

\begin{tabular}{|c|c|c|}
\hline $\begin{array}{c}\text { Active Power } \\
\text { Filter (APF) }\end{array}$ & Shunt APF & Series APF \\
\hline $\begin{array}{c}\text { THD (\%) } \\
\text { without APF }\end{array}$ & $\mathrm{THD}_{\mathrm{I}}=17.09 \%$ & $\mathrm{THD}_{\mathrm{V}}=11.50 \%$ \\
\hline $\begin{array}{c}\text { THD (\%) with } \\
\text { APF }\end{array}$ & $\mathrm{THD}_{\mathrm{I}}=1.13 \%$ & $\mathrm{THD}_{\mathrm{V}}=0.20 \%$ \\
\hline
\end{tabular}

\section{CONCLUSIONS}

By the use of generalized fryze theory in shunt and series active filter, it gave effective result of compensation. It took less computation time than $\mathrm{p}-\mathrm{q}$ theory. Its fundamental is based on the p-q theory but it is not used the Clark transformation to calculate instantaneous active and reactive power for calculation of compensating current. But it used the current minimization technique to calculate compensating current. So, it takes less time than p-q theory.

\section{REFERENCES}

[1]. Hirofumi Akagi, Edsonhirokazu and Mauricio Aredes, instantaneous power theory and applications to power conditioning, a john wiley \& sons, inc., publication, 2007, pp.41-371.

[2]. Emílio F. Couto, Júlio S. Martins, João L. Afonso, "Simulation Results of a Shunt Active Power Filter with Control Based on p-q Theory", Department of Industrial Electronic University of Minho.

[3]. Rosli omar, nasrudin abd rahim and marizan sulaiman, "modeling and simulation for voltage sags/swells mitigation using dynamic voltage restorer (dvr)", journal of theoretical and applied information technology, pp. 464-470, 2009.

[4]. Luís F.C.Monteiro and Maurício Aredes, "A Comparative Analysis among Different Control Strategies for Shunt Active Filters", Federal University of Rio de Janeiro.

[5]. Kian Hoong Kwan, Member, IEEE, Kuan Tak Tan, Student Member, IEEE, Ping Lam So, Senior Member, IEEE, "An Unified Power Quality Conditioner for Load Sharing and Power Quality Improvement IEEE, pp. 963-967, 2012.

\section{BIOGRAPHIES}

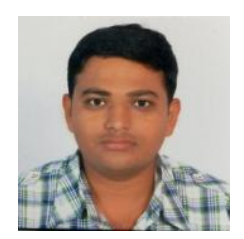

Hardik Jayeshkumar Padariya received the B.E. in Electrical Engineering from C.K.Pithawalla College of Engg. \& Tech., Surat in 2012. Presently perusing as PG Student in Electrical Department, Parul Institute of Engg. \& Tech., Vadodara. His research interests include Renewable Energy Sources, Power Electronics and Power System.

Email:hardik.padariya@ymail.com

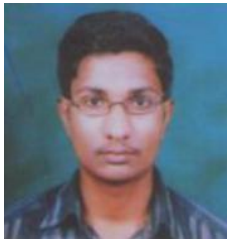

Ch.V.Siva Kumar received the B.Tech in Electrical and Electronics Engineering from Acharya Nagarjuna University Guntur in 2008 and M.Tech in Power electronics and Power systems from K.L.University Guntur in 2011. Presently working as Asst.Proff in Electrical Department, Parul Institute of Engineering \& Technology,Vadodara. His research interests include Power Systems, Finite Element method and High Voltage Engineering.

Email:sivakumar_veera@yahoo.com

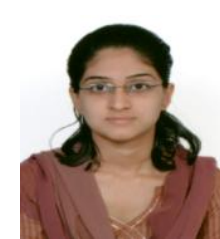

Chandni Yogeshkumar Joshi received the B.E. in Electrical Engineering from Vidhyabharti Trust Inst. of Technology \& Research, Bardoli in 2012. Presently perusing as PG Student in Electrical Department, Parul Institute of Technology, Vadodara. Her research interests include Renewable Energy Sources and Power Electronics.

Email:chandnijoshi3110@gmail.com 